学術論文

\title{
運動準備電位による四肢動作推定
}

\section{Limb motion estimation by Bereitschafts Potential}

北山 真平*1 (学生員), 佐々木 実*1 (正員), 伊藤 聡 ${ }^{* 1}$, 安田 晴信*1，小嶋 俊史 ${ }^{* 1}$

Shimpei KITAYAMA(Stu.Mem.), Minoru SASAKI(Mem.), Satoshi ITO, Harunobu YASUDA, Toshihumi KOJIMA

\begin{abstract}
Motions estimation utilizing EEG can develop devices supporting the elderly and disabilities. This paper investigated a possibility of limb motion estimation using Bereitschafts Potential (BP). BP means voltage variation of EEG just before motions. To estimate, neural network was introduced. Three types of processed signal were used as the input. The types of signal processing were FFT, increment and normalization. The best signal processing of them was normalization, and the accuracy rate was $89.0 \%$.
\end{abstract}

Keywords: EEG, Bereitschafts Potential (BP), motion estimation, man-machine interface, neural network.

\section{1 緒言}

近年，我が国では総人口に占める高齢者の割合が 20\%を超え少子高齢社会となった。こうした背景から， 障害者の人数も増加しており, 介護者の負担が増加し ている。そのため, 介護福祉分野において早急な整備・ 設備の充実が求められている[1]。

このような問題を解決するために近年, 工学分野で は生体信号を用いた機器の開発研究が行われている。 生体信号は直感性に優れており, 測定も簡単にできる。 そのため, 生体信号を用いた機器は, 低負荷かつ扱い 易く, 介護者の負担軽減だけでなく, 被介護者の自立 支援をサポートすることが出来る。

脳波は生体信号の中でも最高次の信号であるとい われており，潜在的に多くの情報を含んでいる。その ため，脳波を用いた動作推定や機器の開発が多く行わ れており, とりわけ, 事象関連電位などの動作後に現 れる脳波の大きな変化を特徴量として用いていること が多い。武藤らの研究[2]ではそれらの特徴量を用いた 指動作の判別において $84.25 \%$ と高い精度での判別が 可能であることを証明している。

しかし，それらの判別結果を入力として機器の操作 などを行う場合に, 動作後に現れる変化を用いるため, 動作と機器の動きにタイムラグが生じてしまう。そこ

連絡先：佐々木 実， 广501-1193 岐阜県岐阜市柳戸 1-1， 岐阜大学工学部機械工学科,

e-mail: sasaki@gifu-u.ac.jp

${ }^{* 1}$ 岐阜大学
で，その問題を解決するために運動準備電位 (Bereitschafts Potential：BP)という脳波の特徵に着目し た。

BP は人の随意運動時に, 動作の約 $0.5 \sim 1$ 秒前に現れ る電位変化である。BP を用いた研究では発生時の識別 [3]や指動作の識別[4]などがあるが, 多くは動作との関 連性を検討するものが多く, 動作推定まで行っている ものは少ない[5]。

そこで本研究では BP による四肢動作推定を行う。 具体的には BP が現れる区間に信号処理を施し，二ュ ーラルネットワークを用いた推定を行う。その結果, 推定可能かどうか, また可能ならばどのような特徵量 が有効かについて検討する。

\section{2 脳波と運動準備電位}

脳波とは，脳が働いている時の電気活動を捉えたも ので，頭部に装着した電極から観測される電位の時間 変化を記録した波形である。脳波は常に摇らいでいる 自発的な電位変化であり, 手足などの動作時には動作 の後に大きな変化が現れる。

一方，運動準備電位(BP)は，動作開始の約 $0.5 \sim 1$ 秒 前から 0.2 秒前にかけて現れる微小な電位変化である。 BP は広汎な大脳皮質の随意運動に対する準備状態を 反映しており, 一次運動野, 補足運動野でみられる[6]。

\section{3 脳波の測定方法}

\section{1 生体信号検出装置}

本研究では, 株式会社 脳機能研究所の「感性スペ 
クトル解析システム」を使用して脳波を測定する。 Fig.1 に実験装置の構成を示す。

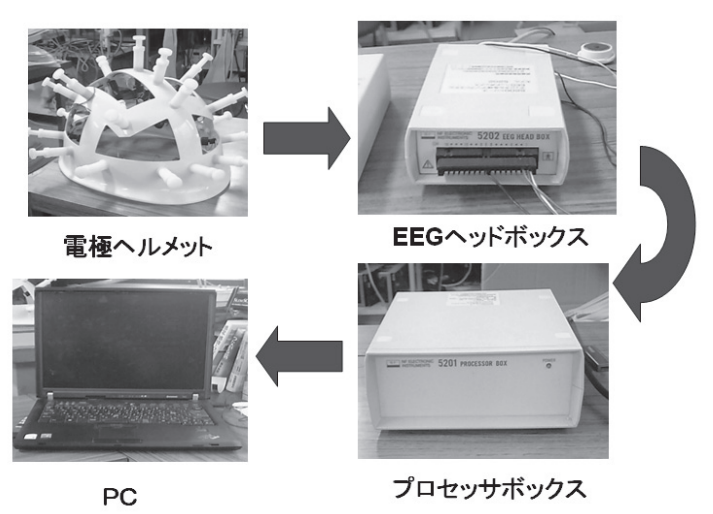

Fig.1 Experimental system.

電極が付いているヘルメットから脳波を抽出し， $\mathrm{HEAD} \mathrm{BOX}$ で $\mathrm{A} / \mathrm{D}$ 変換と増幅を行う。次に PROCESSOR BOX でデジタルフィルタ処理を行う。そ して，これらの処理が行われた脳波のデータをパーソ ナルコンピュータ $(\mathrm{PC})$ に取り込む。

脳波の導出には，右耳架を基準電極とする，右耳架 単極誘導を用いる。また電極位置には，国際的に標準 とされている国際 10-20 法を基に, Fig.2 に示寸右耳朵 A2 を除く 14 か所の電極で測定を行う。また, サンプ リング周波数は $200[\mathrm{~Hz}]$ とし, 各フィルタの設定を Table.1 に示す。

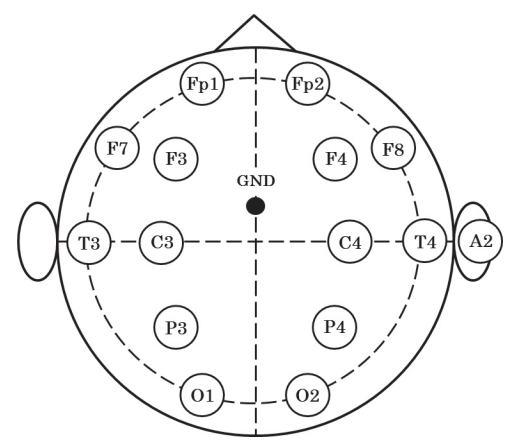

Fig.2 Position of electrode.

Table.1 Setting of digital filter.

\begin{tabular}{|c|c|c|}
\hline & High-Pass Filter & Low-Pass Filter \\
\hline Cutoff frequency & $1.6[\mathrm{~Hz}]$ & $60[\mathrm{~Hz}]$ \\
\hline Attenuation frequency & $-12[\mathrm{~dB} / \mathrm{oct}]$ & $-12[\mathrm{~dB} / \mathrm{oct}]$ \\
\hline
\end{tabular}

\section{2 実験方法}

被験者は24歳の男性 5 人で, いずれも右利きである。 実験に用いる動作は左右の腕と足の昇降動作で，被験 者は着席している状態で行う。腕動作は肘を伸ばした まま肩関節を動かして腕を挙げ，足動作は腿を “へそ” のあたりまで引き上げる動作を行う。なお，被験者は これらの動作を開眼状態で行う。

測定方法は，まず，測定開始から 2 秒間は何もしな い安静状態で待機してもらい，測定開始から 2 秒後に ビープ音と PC 画面上に動作可能の合図を表示する。 この合図の後, 被験者は 5 秒以内に任意のタイミング であらかじめ指定しておいた動作を行う。実験中，5 秒間が分かるように，合図と同時にカウントダウンを PC 画面上に表示する。ただし，合図から 5 秒が経過す るまでは腕または足を降ろさず，挙げた状態を維持し てもらう。合図から 5 秒が経過したとき，PC 画面上に 動作終了の合図を提示し, これ以降 3 秒以内に腕また は足を降ろしてもらう。

以上の流れが 1 回分の測定で，これを同じ動作で連 続 15 回行う。15 回測定が終了したら 3 分ほど休憩を 取り, 再び 15 回測定を行う。この繰り返しにより, 各 動作 30 回測定する。また, 測定は 2 日分(Day1,Day2) 行う。つまり, 1 人の被験者から 30 回分 $\times 4$ 動作 $\times 2$ 日分 $=240$ データが得られ，1つの動作については 30 回 $\times 5$ 人 $\times 2$ 日分 $=300$ データを得ることになる。Fig.3 に被験者 $\mathrm{A}$ の Day1の右腕動作時の波形を示す。なお, 本研究では挙げる動作を解析対象とするため, 脳波の 測定は前半の 7 秒間だけ記録する。また，各電極の波 形の縦軸は電圧であり，範囲はー100 100[ $\mu \mathrm{V}]$ である。

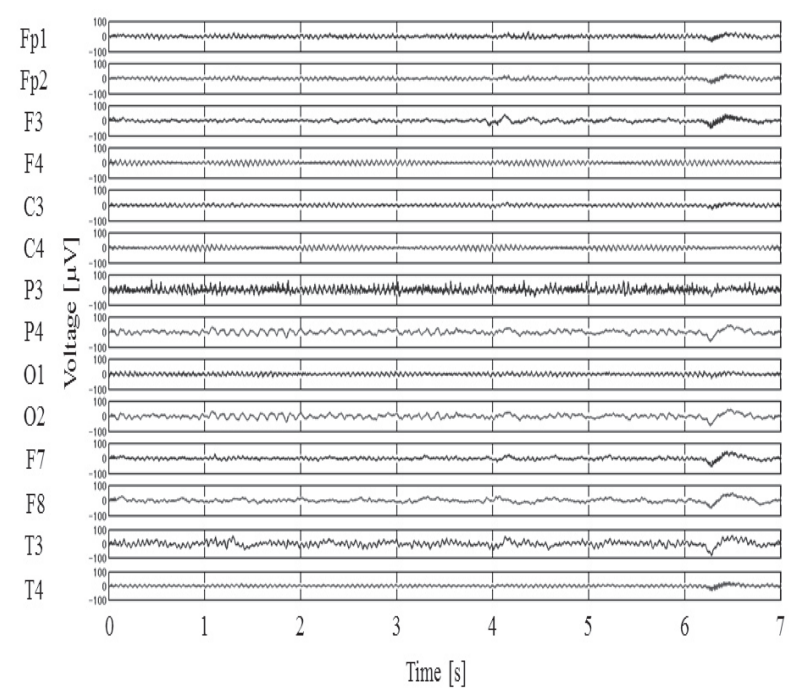

Fig.3 Results of EEG with the right arm motion. 


\section{4 解析対象区間}

本研究では BP を用いるため, 測定した 7 秒間の脳 波すべては用いない。また, BP は現れる範囲が限定さ れているため, 電極の数も限定される。以上のことか ら, 本研究で動作推定に用いる電極と BP を含む区間 (本研究では解析対象区間と呼ぶ)を決める。

\section{1 電極の選定}

BP は 2 章で述べたように一次運動野や補足運動野 で現れる。また, 発生中心部は Fig.4 中の $\mathrm{Cz}$ で, そこ から左右対称に現れると考えられている。そこで，本 研究では以下に示寸理由から, Fig.4 中の太い○の6つ の電極を用いる。

- $\mathrm{C} 3, \mathrm{C} 4$ : BP の発生中心付近にあたる。

- $\mathrm{F} 3, \mathrm{~F} 4$ : 補足運動野にあたる。

○ P3,P4: 運動野と関係性がある体性感覚野にあたる。

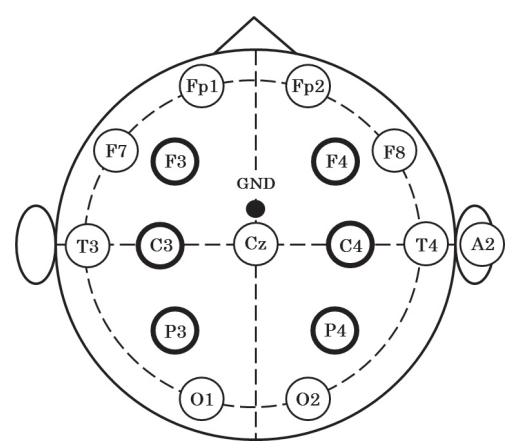

Fig.4 Electrode positions used in motion estimation.

\section{2 解析対象区間}

BP は, 動作をいら行うか予め決めていた場合には 1 秒前から，いつ行うか予定していない，いわば「ひと りでに」行動したくなった場合には 0.5 秒前から現れ ることが明らかにされている[6]。そこで本研究では, 被験者の意識の持ち方を考慮し, 動作前の 1 秒間を解 析対象として用いる。動作と Fig.3 のような脳波の変 化は関係していると考えられるため，この変化を動作 のタイミングとする。以上の観点から, 解析対象区間 の決め方を以下に示す。

1. 4.1 で選定した 6 電極の時刻毎の合計電圧值を算 出し，最大合計值を記録した時刻を $\mathrm{M}$ とする。

2. M から 1.2 秒前を $\mathrm{S}$ と決める。

3. $\mathrm{S}$ からの 1 秒間を各電極の解析対象区間と寸る。

Fig.5 に被験者 A，Day1 の解析対象区間の波形を示 す。なお, 各電極の縦軸の範囲は Fig.3 と同じである。

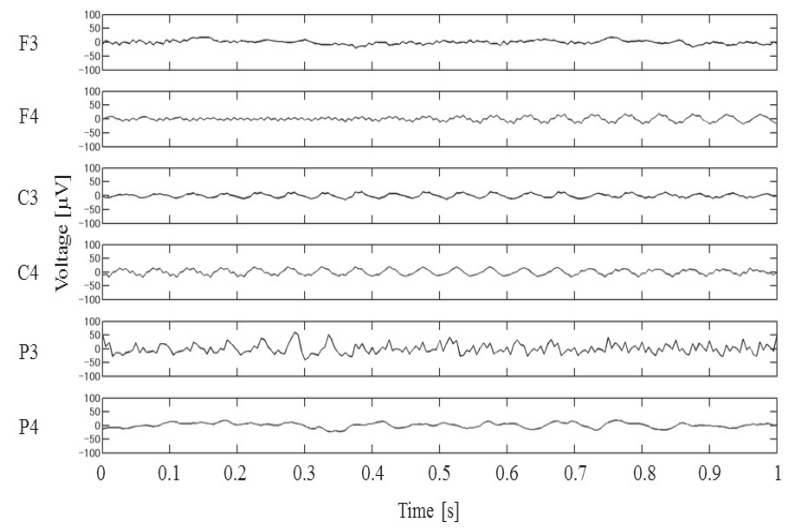

Fig.5 Analysis objects section with the right arm motion.

\section{5 特徵量抽出}

動作ごとのより顕著な特徵を得るために, 本研究で は3つの信号処理を行う。

\section{1 高速フーリエ変換(FFT)}

解析対象区間に対して FFT を行い, パワースペクト ルの波形を特徽量として用いる。Fig.6の上図に被験者 A，Day1 の右腕動作時を，下図に左足動作時の波形を 示す。なお，各電極の縦軸の範囲は $0 \sim 5\left[\mu V^{2}\right]$ である。
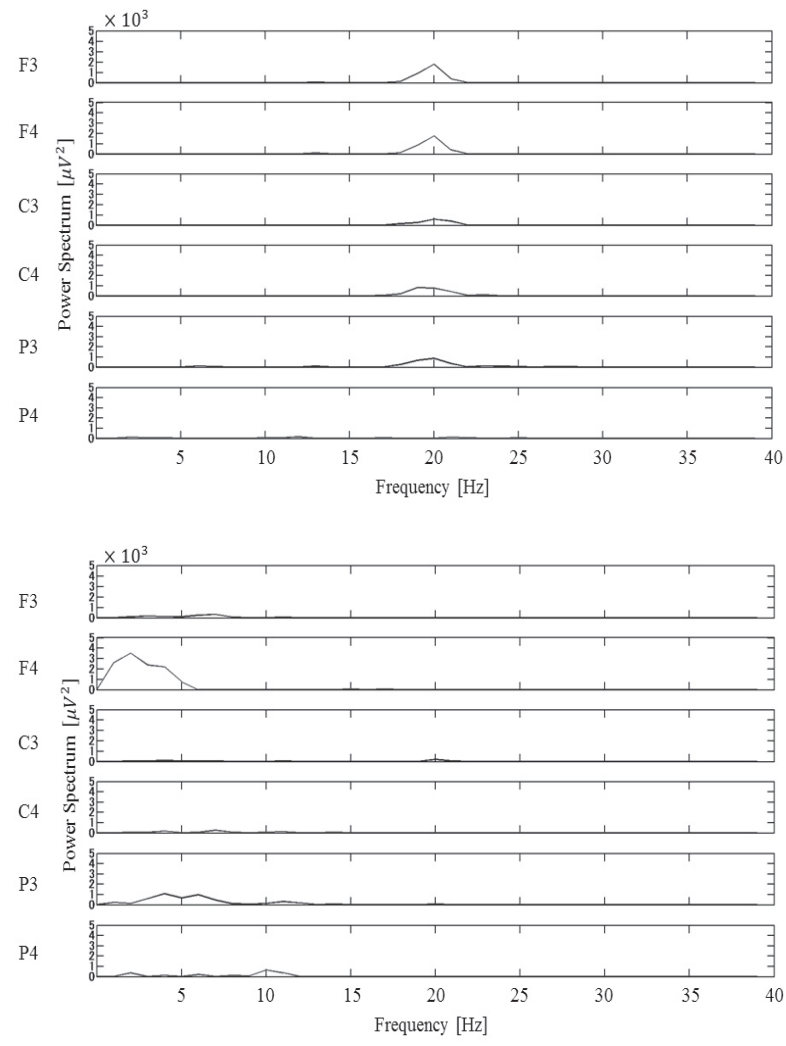

Fig.6 Results of FFT analysis of analysis objects section. 


\section{2 増加量}

BP は 0.3 0.4[ $[\mu \mathrm{V} / 0.1 \mathrm{~s}]$ の特徴を有していることが明 らかにされている[5]。そこで，[0.1 秒ごとの増加量 10 個] + [1 秒間での増加量], 計 11 個をまとめたデータを 特徵量として用いる。Fig.7 の上図に被験者 A, Day1 の左腕動作時を，下図に右足動作時の波形を示す。な お，各電極の縦軸の範囲はー20 20[ $\mu \mathrm{V}]$ である。

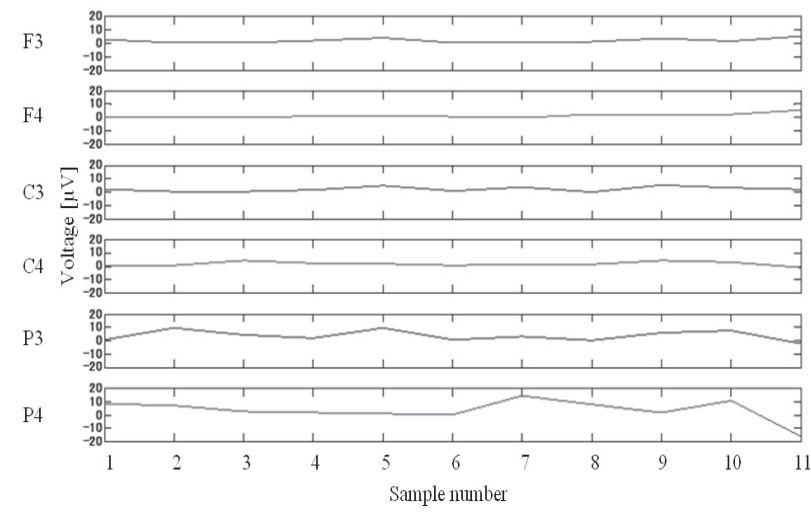

F3

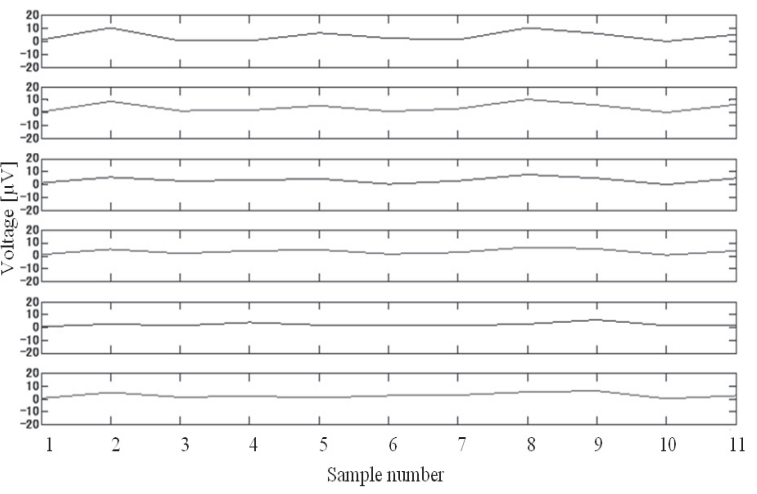

Fig.7 Results of increment analysis of analysis objects section.

\section{3 正規化}

脳波は被験者や日時などにより, 電圧值が変化する。 そこで，測定された脳波の最大振幅值で割る正規化を 行うことで，単位系によらないー1 1 の範囲の波形に 変形し，脳波に現れる個人差や日時の差を小さくする ことができる。しかし, Fig.3のように本研究での脳波 の最大振幅值は動作時であり，この時の值で正規化を 行うと解析対象区間の值が極めて小さくなってしまい, BP を捉える事が難しくなってしまう。

そこで，本研究ではまず各電極のピーク值を求め, 電極別に正規化を行う。次に，正規化された波形で, 4.2 で説明した時刻 $\mathrm{M}$ と $\mathrm{S}$ を算出し, 解析対象区間を 決める。こうして決められた解析対象区間の脳波にお いて, 電極ごとにピーク值を求めて再度正規化を行う
ことで，解析対象区間をー1 1 の波形に正規化するこ とができる。Fig.8の上図に被験者 A，Day1 の右腕動 作時，下図に左足動作時の解析対象区間を正規化した 波形を示す。

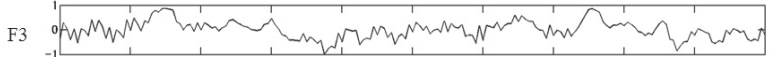

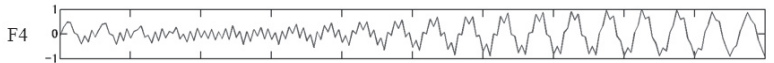

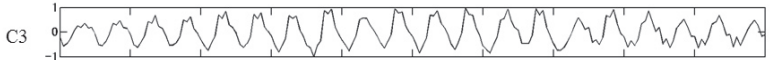

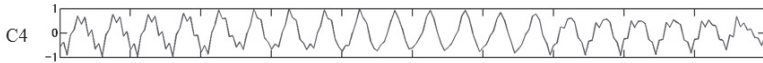

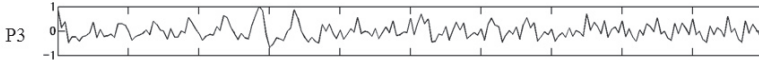

P4

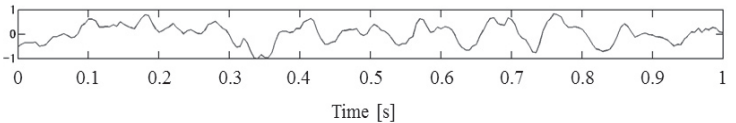

F3 of ow

F4

C3

C4

P3

P4

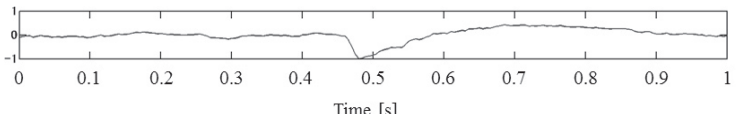

Fig.8 Results of normalization analysis of analysis objects section.

\section{4 考察}

各特徴量について動作ごとに特徵が現れたか検討 する。

まず，FFT では腕動作時は $20[\mathrm{~Hz}]$ 付近で，足動作 時では 0 5[Hz] 付近でパワースペクトルが最大となる 傾向が見られた。これは脳波が意識の強い動作をする と高い周波数が大きくなり、弱い動作をすると低い周 波数が大きくなることが関係し、人が歩く際に意識し て足を動かさないように、足動作は腕動作よりも意識 が弱いため、このような傾向になったと考えられる。 また，腕動作時よりも足動作時の方が，パワースペク トルが大きい傾向がある。これは筋肉量が影響してお り, 腕よりも足の筋肉の方が多いためだと考えられる。 他にも，右腕，右足動作時には左側の電極(F3, C3, P3) のパワースペクトルが, 左腕, 左足動作時には右側の 電極(F4，C4，P4)のパワースペクトルが大きくなる傾 向があった。これは, 動作する部位と左右逆側の脳が 対応していることが理由と考えられる。

次に，増加量では左腕動作時は P4 の 1 秒間の増加 
量が約- $10[\mu \mathrm{V}]$ であり, 他の動作とは違う傾向が見ら れた。これは動作の部位と逆側が活性化することから， P4 が右側にあり, かつ運動野と関係のある部分の電 極であるためと考えられる。また, 右足動作時の波形 が他の動作と比べて増加量の増減が少ない傾向が見 られた。足動作は腕動作よりも意識して動か寸動作で はないため, 増加量が少なくなったものと考えられる。

最後に正規化では, 動作側とは反対側の電極の波 形に変化が見られ, 右腕, 右足動作時の方が左腕, 左 足動作時に比べて波形の変化が大きい傾向があった。 これは利き手の方を普段からよく使用するので, 利 き手に対応する脳（右利きの場合は左脳）の方が活 性化しやすいためであると考えられる。さらに, 正 規化されたことによって, 解析対象区間で最も変化の あった部分が強調された。日時等の違いによる電圧值 の変化誤差が小さくなったことが原因と考えられる。 以上の観点から, 3 つの特徵量は動作ごとの違いを顕 著にできるものであると考えられるため, これら 3 つの特徽量による動作推定を試みる。

\section{6 四肢動作推定}

本研究では上記 3 つの特徵量を入力データとして, ニューラルネットワークによる動作推定を行う。

\section{1 ニューラルネットワーク}

本研究では, 階層型ニューラルネットワークを用い る。階層型ニューラルネットワークには, 単純パーセ プトロンと多層パーセプトロンがあるが，本研究では 多層パーセプトロンを用いる。理由として, 単純パー セプトロンではFig.8のような AND 関数は実現できて も, Fig.9 のような XOR 関数は必ずしも実現できると は限らないからである。ニューラルネットワークは, 処理ユニットの状態やニューロン間の結合の情報伝達 率(結合重み係数)を変化させることによって入出力関 係を変えることが出来る。出力層のユニットの出力を 教師信号と比較して, 結合の重みを変化させていくこ とをニューラルネットワークの学習と呼ぶ。入力層と 出力層の 2 層から構成される単純パーセプトロンの学 習では 1 段だけの結合しか修正できないため, 線形分 離しかできない。なので, Fig.9のような線形分離でき ない問題において, 2 本の直線で分離, 又は点線のよ うな曲線で分離することが出来ない。

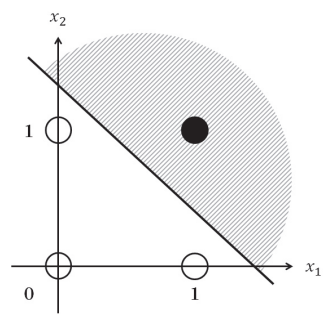

Fig.8 AND function.

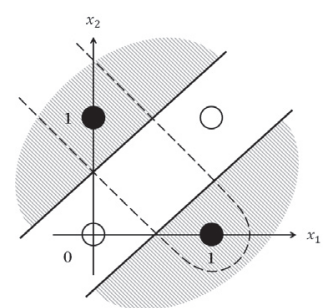

Fig.9 XOR function.
一方, 多層パーセプトロンは入力層, 複数の中間層, 出力層から構成される。中間層が入ることで, 結合修 正可能な層間結合が増え, 非線形分離が可能となる。 ただし， 2 段の結合をシステマチックに修正できる学 習則が必要になる。この学習則について, 多層パーセ プトロンにおける学習にはいくつかあるが，その中で も最も盛んに用いられているのが誤差逆伝播法(バッ クプロパゲーション)である。誤差逆伝播法は, 出力層 と教師信号の誤差を出力層から入力層に向かって逆伝 播させて重みを調整していく。この学習法によって, 教師信号をま䄈ることが出来るようにユニット間の結 合の強さ，つまりネットワークの内部構造が修正され ていく[7]。

\section{2 四肢動作推定}

出力層のユニット数は 4 つで, 各動作に対応してい る。入力層のユニット数, つまり入力層に与えるデー タ数は以下の通りである。

$\cdot$ FFT : 100 データ (1 秒間の FFT 波形の半分) $\times 6$ 電極 $=600$ データ

• 増加量 : 11 データ $(0.1$ 秒ごとの増加量 10 個 +1 秒間 での増加量 1 個 $) \times 6$ 電極 $=66$ データ

-正規化 : 200 データ $(1$ 秒間の正規化波形 $) \times 6$ 電極 $=1200$ データ

中間層は 1 層で, ユニット数は FFT と増加量が 50 , 正規化が 10 である。出力関数は, 中間層がシグモイド 関数を, 出力層が線形関数である。収束誤差は $10^{-4}$ で 最大学習回数は 10 万回である。最後に最適化手法に関 して, FFT と増加量は共役勾配法を, 正規化は最急降 下法を用いる。なお，これらの設定は試行錯誤的に求 めており，最も結果が良かった場合を示している。評 価方法は各動作 30 回分のデータの内, 29 個を学習に, 1 個を判別に使用し, 判別に用いるデータを順に代え ていくクロスバリデーション法により, 30 回の動作推 定を 2 日分行う。なお，学習と判別には同一被験者, 同日のデータを用いて行う。

以上の設定を用いて行った動作推定の結果を 
Table.2 Table.4 に示す。表中の A E は被験者を, RA は右腕，LA は左腕，RL は右足，LL は左足を表す。

Table.2 Results of state estimation (FFT).

\begin{tabular}{|c|c|c|c|c|c|}
\hline & RA & LA & RL & LL & Total \\
\hline \multirow{2}{*}{$\mathrm{A}$} & $58 / 60$ & $59 / 60$ & $57 / 60$ & $52 / 60$ & $226 / 240$ \\
& $(96.7 \%)$ & $(98.3 \%)$ & $(95.0 \%)$ & $(86.7 \%)$ & $(94.2 \%)$ \\
\hline \multirow{2}{*}{$\mathrm{B}$} & $46 / 60$ & $51 / 60$ & $51 / 60$ & $56 / 60$ & $204 / 240$ \\
& $(76.7 \%)$ & $(85.0)$ & $(85.0)$ & $(93.3 \%)$ & $(85.0 \%)$ \\
\hline \multirow{2}{*}{$\mathrm{C}$} & $50 / 60$ & $47 / 60$ & $53 / 60$ & $54 / 60$ & $204 / 240$ \\
& $(83.3 \%)$ & $(78.3 \%)$ & $(88.3 \%)$ & $(90.0 \%)$ & $(85.0 \%)$ \\
\hline \multirow{2}{*}{$\mathrm{D}$} & $57 / 60$ & $50 / 60$ & $54 / 60$ & $47 / 60$ & $208 / 240$ \\
& $(95.0 \%)$ & $(83.3 \%)$ & $(90.0 \%)$ & $(78.3 \%)$ & $(86.7 \%)$ \\
\hline \multirow{2}{*}{$\mathrm{E}$} & $51 / 60$ & $51 / 60$ & $51 / 60$ & $48 / 60$ & $201 / 240$ \\
& $(85.0 \%)$ & $(85.0 \%)$ & $(85.0 \%)$ & $(80.0 \%)$ & $(83.8 \%)$ \\
\hline
\end{tabular}

Table.3 Results of state estimation (Increment).

\begin{tabular}{|c|c|c|c|c|c|}
\hline & RA & LA & RL & LL & Total \\
\hline \multirow{2}{*}{$\mathrm{A}$} & $52 / 60$ & $55 / 60$ & $53 / 60$ & $48 / 60$ & $208 / 240$ \\
& $(86.7 \%)$ & $(91.7 \%)$ & $(88.3 \%)$ & $(80.0 \%)$ & $(86.7 \%)$ \\
\hline \multirow{2}{*}{$\mathrm{B}$} & $50 / 60$ & $50 / 60$ & $48 / 60$ & $52 / 60$ & $200 / 240$ \\
& $(83.3 \%)$ & $(83.3 \%)$ & $(80.0 \%)$ & $(86.7 \%)$ & $(83.3 \%)$ \\
\hline \multirow{2}{*}{$\mathrm{C}$} & $52 / 60$ & $45 / 60$ & $57 / 60$ & $51 / 60$ & $205 / 240$ \\
& $(86.7 \%)$ & $(75.0 \%)$ & $(95.0 \%)$ & $(85.0 \%)$ & $(85.4 \%)$ \\
\hline \multirow{2}{*}{$\mathrm{D}$} & $51 / 60$ & $48 / 60$ & $56 / 60$ & $49 / 60$ & $204 / 240$ \\
& $(85.0)$ & $(80.0)$ & $(93.3 \%)$ & $(81.7 \%)$ & $(85.0 \%)$ \\
\hline \multirow{2}{*}{$\mathrm{E}$} & $46 / 60$ & $45 / 60$ & $48 / 60$ & $51 / 60$ & $190 / 240$ \\
& $(76.7 \%)$ & $(75.0 \%)$ & $(80.0 \%)$ & $(85.0 \%)$ & $(79.2 \%)$ \\
\hline
\end{tabular}

Table.4 Results of state estimation (Normalization).

\begin{tabular}{|c|c|c|c|c|c|}
\hline & RA & LA & RL & LL & Total \\
\hline \multirow{2}{*}{$\mathrm{A}$} & $53 / 60$ & $53 / 60$ & $51 / 60$ & $50 / 60$ & $207 / 240$ \\
& $(88.3 \%)$ & $(88.3 \%)$ & $(85.0 \%)$ & $(83.3 \%)$ & $(86.3 \%)$ \\
\hline \multirow{2}{*}{$\mathrm{B}$} & $51 / 60$ & $51 / 60$ & $50 / 60$ & $57 / 60$ & $209 / 240$ \\
& $(85.0 \%)$ & $(85.0 \%)$ & $(83.3 \%)$ & $(95.0 \%)$ & $(87.1 \%)$ \\
\hline \multirow{2}{*}{$\mathrm{C}$} & $56 / 60$ & $56 / 60$ & $58 / 60$ & $52 / 60$ & $222 / 240$ \\
& $(93.3 \%)$ & $(93.3 \%)$ & $(96.7 \%)$ & $(86.7 \%)$ & $(92.5 \%)$ \\
\hline \multirow{2}{*}{$\mathrm{D}$} & $53 / 60$ & $52 / 60$ & $58 / 60$ & $49 / 60$ & $212 / 240$ \\
& $(88.3 \%)$ & $(86.7 \%)$ & $(96.7 \%)$ & $(81.7 \%)$ & $(88.3 \%)$ \\
\hline \multirow{2}{*}{$\mathrm{E}$} & $60 / 60$ & $56 / 60$ & $50 / 60$ & $52 / 60$ & $218 / 240$ \\
& $(100 \%)$ & $(93.3 \%)$ & $(83.3 \%)$ & $(86.7 \%)$ & $(90.8 \%)$ \\
\hline
\end{tabular}

\section{3 動作推定の考察}

動作推定の結果，5人平均判別率は FFT の場合，両 日合わせて $86.9 \%$ であった。同様に増加量では $83.9 \%$, 正規化では 89.0\%であった。また，動作別に見ても多 くが 80 90\%以上で，低くても 70\%以上の判別率が得 られた。以上から, どの特徴量でも $80 \%$ 以上の判別率 が得られ，特に正規化を用いた場合が最も精度良く判 別できることが分かった。この要因として, 日時の違 い等による電圧值の変化誤差が正規化により小さくな り, 動作ごとの傾向が顕著になったことが考えられる。
他の 2 つの特徵量でも動作ごとに違いが現れているが, それらの変化誤差が判別率に影響したものと考えられ る。

\section{7 結言}

本研究ではBPによる四肢動作推定を行った。まず, BP を含む解析対象区間を決め, 信号処理を行い動作ご との特徴を顕著にした。そのデータを用いてニューラ ルネットワークによる動作推定を行った結果，正規化 を特徴量とした場合に $89.0 \%$ と最も高い判別率が得ら れた。これより, BP による動作推定は可能であること が示された。しかし，本研究では動作時に生じる脳波 のピーク值を用いて BP を含む解析対象区間を求めて いるので，リアルタイムで判別を行った場合，動作と 判別結果がでるまでのタイムラグをなくすことができ ない。そこで，今後は動作前に BP を含む波形を捉え る方法を検討し，リアルタイムで動作とのタイムラグ が生じない判別ができるか検証したい。

(2014 年 3 月 7 日受付)

\section{参考文献}

[1] 田中一男, 松永和之, 堀滋樹 : “移動ロボットの脳動制 御”, IEEE Trans EIS, Vol.124, No.3, pp.890-896, 2004.

[2] 佐々木実, 武藤光, 安田晴信, 伊藤聡 : “脳波を用いた 指動作の推定”, 日本 AEM 学会誌 20(1), pp.256-261, 2012.

[3] 平岩明, 内田典佳, 下原勝憲, 曽根原登 : “随意運動発 生直前の頭皮電位分布パターンのニューラルネットに よる認識”, 電子情報通信学会論文誌 A, Vol.J79-A, No.2, pp.408-415, 1996.

[4] Yong Li, Xiaorong Gao and Hesheng Liu : "Classification of Single-Trial Electroencephalogram During Finger Movement”, IEEE Transactions on Biomedical Engineering, Vol.51, No.6, pp.1019-1025, 2004.

[5] 鬼頭伸和, 五木田健, 伊藤智式: “運動準備電位と筋力 発揮の調節”, 愛知教育大学研究報告, 47(芸術・保健体 育・家政・技術科学編), pp.13-18, 1998.

[6] ベンジャミン・リベット：“マインド・タイム 脳と意 識の時間”, 岩波書店, 2005 .

[7] 国際電気通信基礎技術研究所 : “ニューラルネットワー ク応用”, オーム社, pp.8-11, 1995. 